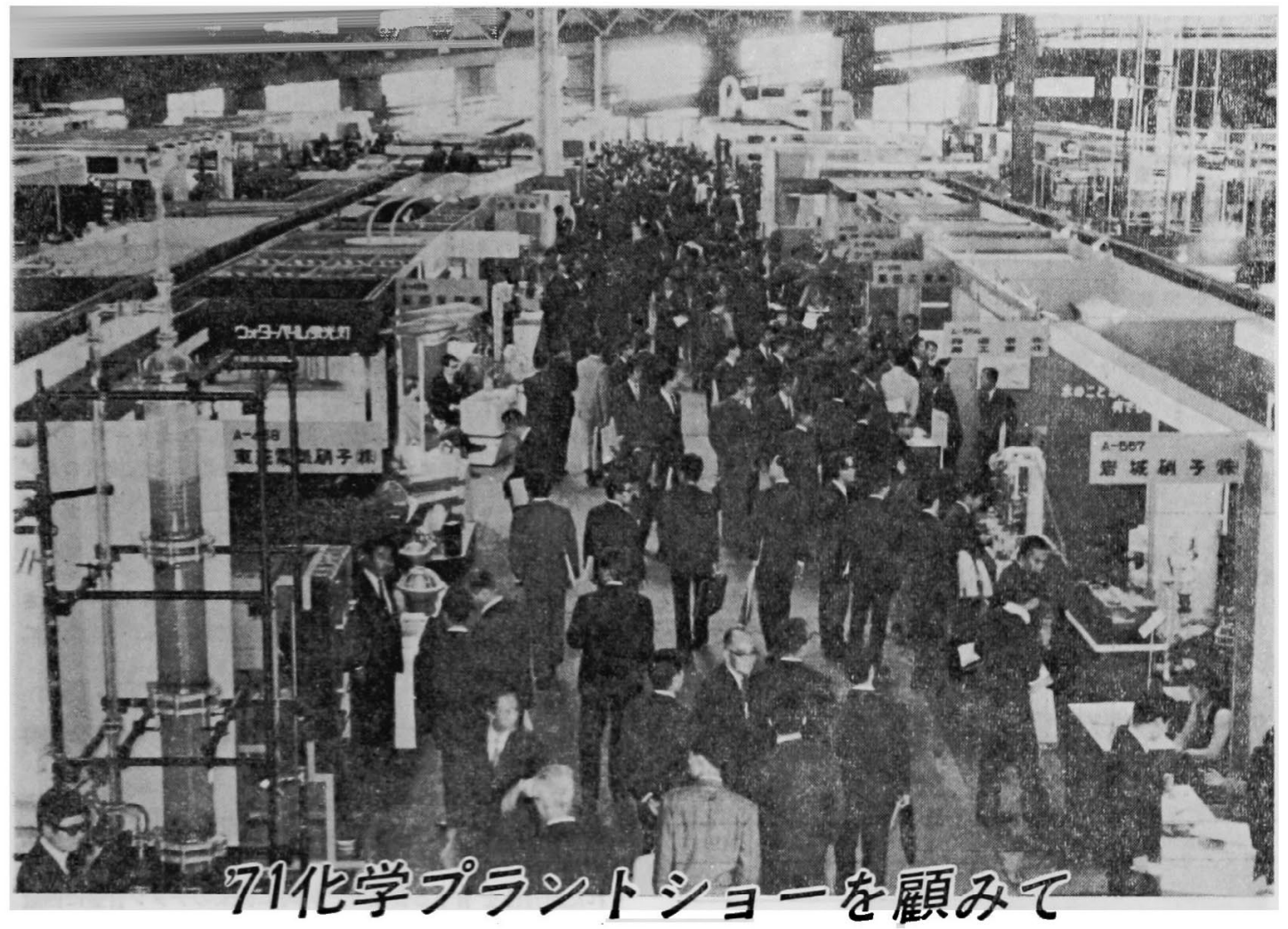

本協会および日本能率協会主催の’71 (第 6 回) 化学プラントショーは昭和 46 年 10 月 15 日から 6 日間東京晴海の国祭貿易センターで, 化学プラント・技術会議は 10 月 16日から 5 日間丸の内東商ビル国際会議場でそれぞれ開催され，いずれも盛況裡に終 アした。

化学ブラント・ショーは 1966 年以来每年開催され今 回で第 6 回を数えるに至ったが，その出品状況る表 1 の ように回を追うことと增加を示してきている。今回は， 265 社 844.5 小間におよぶ最近の化学機械装固ならぴに 材料か展示され 規模内容ともに克实したるのとなり, 14 万名にのぼる来場者を得たことは誠に壳ばしいこと である。

本展示会が出品会社の協力を得て，より多くの有益な 最近情報および業界の趃勢をとらえる場として意莪深い るのを有することを物語るるのといえよ5。ちなみに海 外においては西ドィッのフランクフルトで 3 年に 1 回開 催される ACHEMA および隔年ニューヨークで開催さ れる $\mathrm{CHEM} \cdot \mathrm{SHOW}$ など著名な 展示会があるが, わが 国の化学ブラント・ショーも世界各国からの出品を集め 海外から多数の参会者を得て名実ともに国際的な世界三 大ショーの一つにしたいものである。

出品内容についてみると表 2 のように A 会場 (ドー 厶) では公害防止機器装置, ブラント・エンジニフリ ンク，沪過装直および計测，B 会場（別棟）では化学装 置材料が主流を占めていた。ここの展示物については割 愛するが, 出品者の新旧交替がたいぶあったせいか展示
物の半数以上が昨年出品していなかったものであったよ らである。また傾向として大企業あるいはブラント・エ ソジニアリンクの出品では外国からの尊入技術が多く, 自社開発よりは手間がかからずリスクす少ない外国技術 の導入という考え方が多く見うけられた。

今回の重点テーマ展示コーナーとして,公害防止技術, 化学装置材料および食品機械装洫が企画されたが, 時代 を反映してかとくに公害防止技術関保が多く展示され， 来場者も熱心で, 公害を真剣に解決しようとする業界の 関心と熱意が強く感じとられた。ちなみに次回の重点テ 一マの一つとしてふたたび公害防止技術コーナーが企画 されているが，斯界の成果があがり賑しく注目すべき展 示がなされるものと今から楽しみである。次回にはその 他に粉流体用機械装置コーナーおよぴ化学工業用ポン ブ・ハルブューナーが企画されている。

会場設営にあたっては出品が多くなるにつれて，来場 者が目的展示物を短時間で効率よくみられるようまた会 場における見通しがきくように，なお一層のくふらが必 要であると感じられた。より新しく、より多くの情報を与 えるすのとして，また技術交流の場としてこれをみると き, ショーの会場と技術会誐の会場とが離れていること 
表 1 化学ブラント・ショー出品状況

\begin{tabular}{c|c|c|c|c|c|c}
\hline & 66 & 67 & 68 & 69 & 70 & 71 \\
\hline 出品会社 & 110 & 151 & 209 & 216 & 232 & 265 \\
\hline 出品小間 & 258 & 352 & 458 & 614 & 723 & 844.5 \\
\hline
\end{tabular}

表 271 化学ブラント・ショー出品内容分頶

(O) 印 重点テーマ

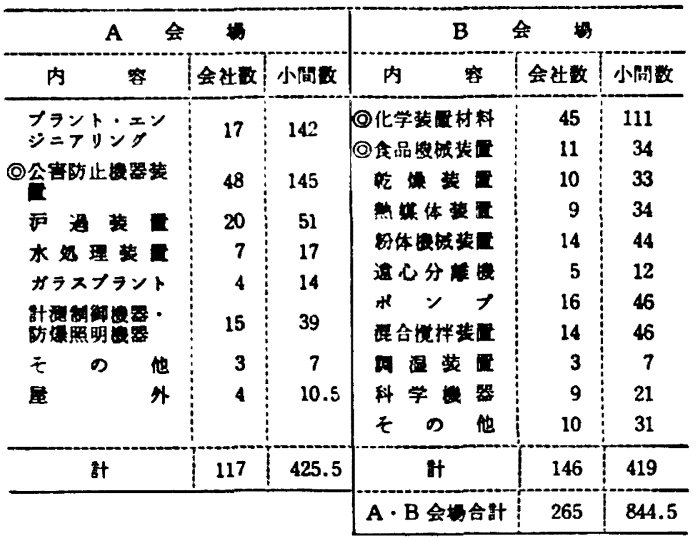

表 $3 ・ 71$ CP アイデア受受買粠品

\begin{tabular}{|c|c|}
\hline 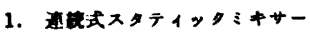 & 大宝産萧（株） \\
\hline 2. ターポフレックストレイ & 铁化学工来（株） \\
\hline 3. ビスター拱抹 & 日本架色溲栊（铢） \\
\hline 4. FAEDIC-NT 合金 & 古河电気化学工乗 (姝) \\
\hline 5. ホをフイルタ: & （株）奥村商会 \\
\hline
\end{tabular}

は著しく上記目的の奻果を隇じているのではなかろら か。もちろん全部の技術会議を啨海会場で実施すること は䇤理で，取重点テーマだけです同一会塯にまとめるこ とができれば来場者に便利で技術交流の实がよりあがる
のではなかろらか。

今回の CP アイデア鿓への応摹は，前回の 19 件に対 して 27 件の多数にのぼったが，その受賞製品名と社名 は衣 3 のおりで，いずれるフイデフ鿓にふさわしいニ ニークな製品であるといえよう。これら製品の特徽につ いて簢に記すと次のとおりである。

1. スタテイックミキサー

スクリュー、モーターなどの聂動部のないミキサーで，パ ブ状のハウジング中に左ねじりおよび右ねじりの螺旋状のセク メントが交互にかつ接触線の方向が 90 度直角に交差するよ5に 数㻌つなぎに溶接されたエレメントを入れた篗造。

2. ターボフレックストレイ

トレイエレメントが強度のある長尺 L 型成形材により粒成さ れており，しかるサボートバーにより支点を中心に一定角度に 回転しうろよ5に支持された梏造。

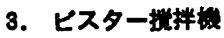

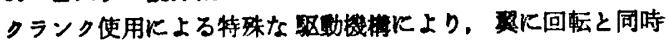

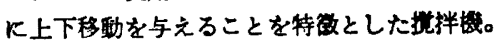

\section{FAEDIC-NT 合金}

$\mathrm{Ni}$ と Ti かi原子比で 1：19 NiTi 金属蔺化合物を基本組成

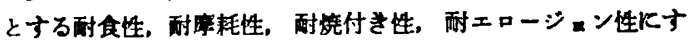
ぐれた諸特性を有する合金で，同時に促来のチタン合金に匹敞 する強度をる持つ金属材料。

5. ホモフィルターミル

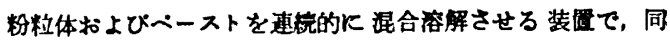
心円カッターとネットスクリーンをる組み合わせた構造。

取後に次回 72 化学ブラント・ショーは, 時を同じく して本協会主催の太平洋化学工学会㖣す開催されるので なお一層盛況が予想される。とくにこの機会に海外より の出品参加と参加者增加対策を触極的に進め，わが国に おける化学ブラントショーおよび化学ブラント技術会鿁 の国際化実現に，大きく前進することができるよ5期待 するむのである。 


\section{'71 CP アイデア賞受賞製品}
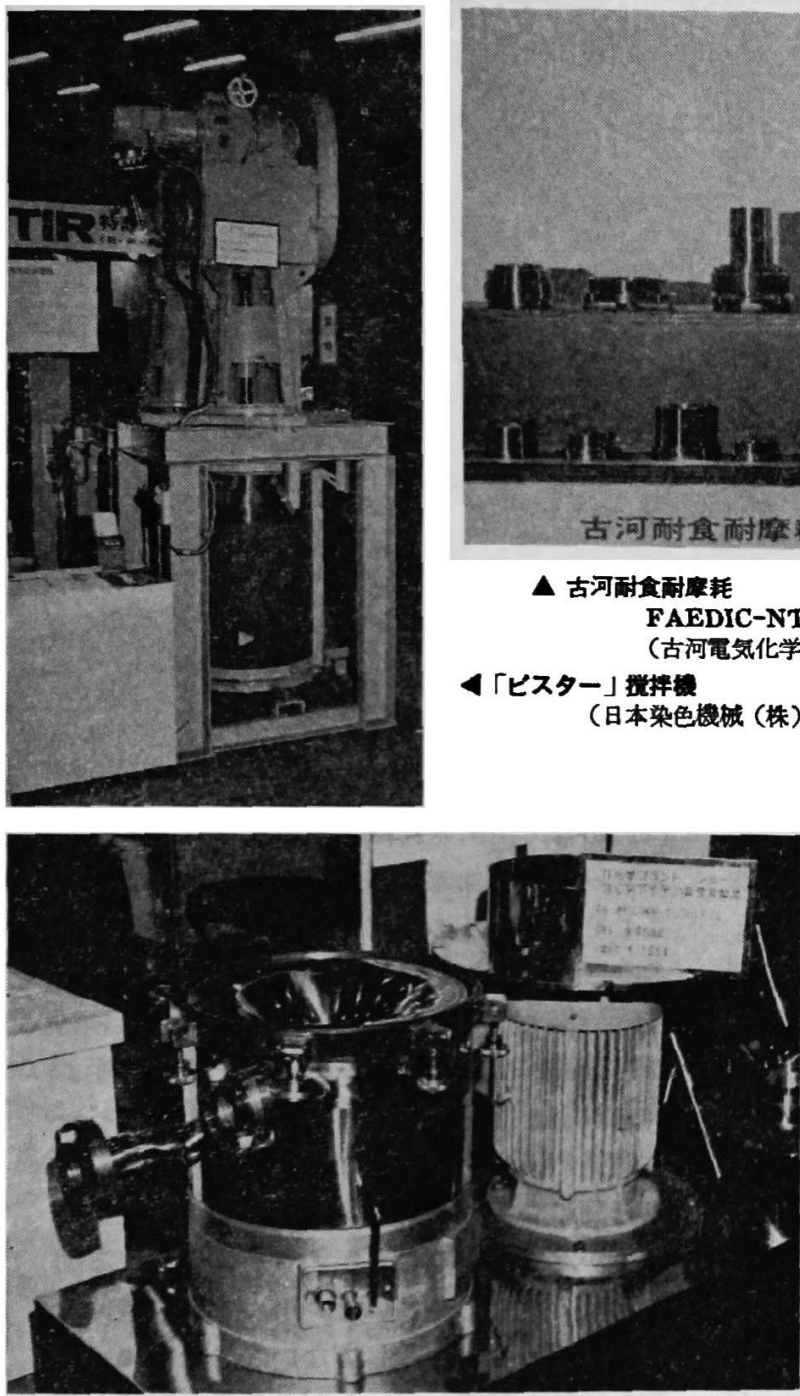

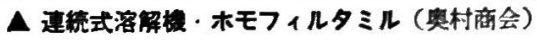

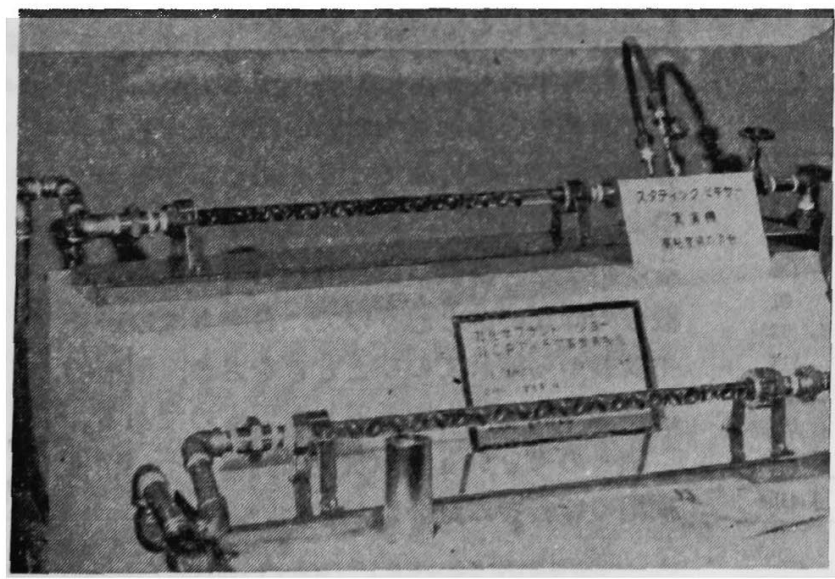

【連绕式スタティックミキサー

(大宝産業 (株))

FAEDIC-NT 合金 (古河電気化学工業(株))

(日本染色機械 (株))

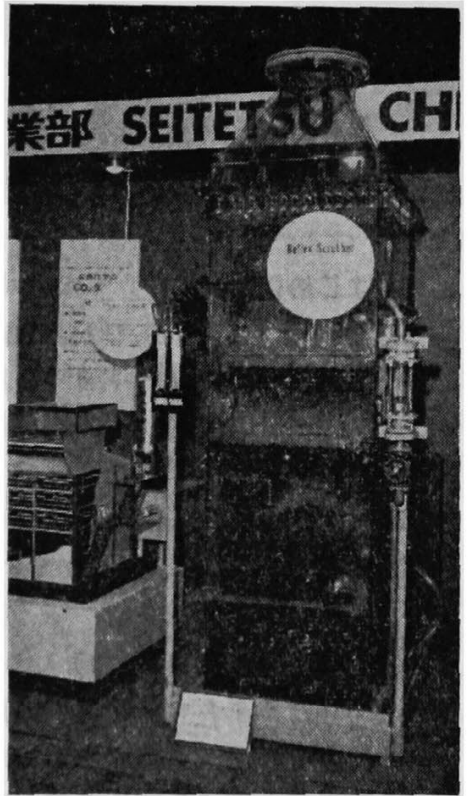

\ターポフレックストレイ (製鉄化学工莱 (蛛))

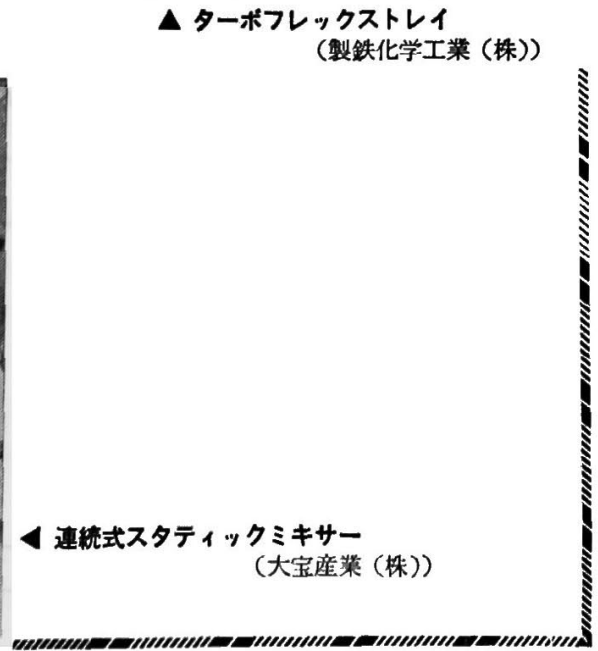

